\title{
Metabolic Role of Non-Specific Immunostimulant (inmunair) in Advanced Healthly of Broilers
}

\author{
Mahfouz M.K ${ }^{1}$, Omyma A.R ${ }^{1}$, Abd El-maksoud H.A ${ }^{1^{*}}$, Abd El-fattah S.A ${ }^{2}$, Sohyla G.M ${ }^{1}$ \\ ${ }^{1}$ Department of Biochemistry, Benha University, Egypt \\ ${ }^{2}$ Department of Pharmacology, Sadat City University, Egypt
}

*Corresponding Author: Abd El-maksoud H.A, Department of Biochemistry, Benha University, Egypt.

\begin{abstract}
The objective of the present study was to evaluate the biochemical effect of Inmunair $17.5^{\circledR}$ administration on broilers. One hundred one day old Cobb broiler chicks were divided into 2 groups: control group (No treatment) and inmunair group (Inmunair 17.5® treated:1.5ml/L to drinking water for 24 hours at first 5 days of life 1 day before vaccination and 2 days after vaccination). Blood samples were collected at 7, 21 and 31 days of life. Body weight was registered at 10 and 34 days of life. Results revealed that inmunair caused no significance on serum (TP, Alb, AST, ALP, Ca, Cholesterol, HDL, LDL, CRP, IL6) but caused significant decrease in Na all over experimental period, significant decrease in cortisol at 7 and 21 days of life, significant increase in IL2 at 31 days of life and high significant increase in immunoglobulins IgG and IgM all over the experimental period. The increase in body weight wasn't significant. In conclusion the obtained result show thatinmunair17.5canbeusedasasafeimmunostimulantthatcanreducestressafter vaccination and cause antibody response in broilers.
\end{abstract}

Keywords: Immunostimulant, Inmunair, Lipid profile, Liver function

\section{INTRODUCTION}

Immunostimulants are products that induce non antigen enhancement of innate or adaptive immunity (Ryan et al. 2010) and tend to stimulate immunity with minimal or no tissue damage (Mutwiri et al. 2007). In this way, the administration of non-specific immunostimulants has been used in horses (Flaminio et al.1998, Rush 2006, Ryan et al. 2010) for treatment of respiratory diseases and at length as adjuvant to veterinary vaccines (Mutwiri et al. 2007). The mechanism of action of non-specific immunostimulant is the activation of macrophages which subsequently activate terminal immune response such as antigen uptake, cytotoxicity, phagocytosis, cytokine release and antibody production (Flaminio et al. 1998, Rush 2006).

Inmunair 17.5® (Propionibacterium acnes, and E. coli lipopolysaccharides) is one of the commercial products available in the Egyptian market as nonspecific immunostimulant for the chicken farms. Propionibacterium acnes, formerly known as Corynebacteriumparvum, is a non-spore Gram positive bacteria and is considered an opportunistic pathogens (Perry \& Lambert 2006). $P$. acnes is a potent stimulator of the reticuloendothelial system (RES) (Megid \& Kaneno 2000, Megid et al. 2004) that enhanced both macrophage and lymphocyte function, natural killer cytotoxicity and cytokine production in laboratory animals. It has been recognized that $P$. acnes contribute the induction of pro-inflammatory cytokines IL- $1 \alpha$, IL- $1 \beta$, IL8 and TNF- $\alpha$ (Perry \& Lambert 2006) and increase IL- 10 in mice infected with street rabies virus (Megid et al. 2004). LPS is a large molecule consisting of a lipid component and a polysaccharide that contains repetitive glycan polymers called $\mathrm{O}$-antigens. The polysaccharide component elicits a strong immune response in animals, including the production of cytokines by phagocytes and complement activation. LPS can also cause changes in the physical condition of an animal, including piloerection, inactivity, loss of thermoregulation and hypotension in a condition known as endotoxic shock (Murphy 2011).

LPS has been investigated as an immunostimulant used at low doses. In fish, it has been shown to increase the phagocytic 
activity of innate immune cells, and in addition, to increase the levels of lymphocytes, which are adaptive immune cells (Nya and Austin 2010).

\section{MATERIALS AND MeTHOdS}

\subsection{Birds}

One hundred one day old Cobb broiler chicks were commercially purchased from El-Nile Company for poultry and ration, Cairo, Egypt. All chicks were housed in 2 separate ventilated rooms and maintained on a 24-h constant-light program and adjusted temperature. The experiment carried out in central animal laboratory, Benha University, Egypt.

\subsection{Inmunair17.5®}

Oral solution Inmunair 17.5® (LABORATORIOS CALIER, Spain for ATCO Pharma Co, Egypt) which consists of (inactivated cells of propionibacteriumacnes $0.17 \mathrm{mg}$, lipopolysaccharide from E. coli 0.05 $\mathrm{mg}$, Thiomersal, $0.10 \mathrm{mg}$ and Excipient q.s 1 $\mathrm{ml})$.

\subsection{Experimental Design}

The chicks were allocated into 2 groups (50 birds for each); group (1) kept as control group (no treatment), group (2) supplemented with inmunair $17.5 \AA(1.5 \mathrm{ml} / \mathrm{L}$ to drinking water for 24 hours at first 5days of life,1day before vaccination and 2 days after vaccination).

\subsection{Vaccination Program}

The birds of the two groups were vaccinated against Newcastle disease at 7 days of age (HB1, Pfizer), lasota at 19 and 29 days of age and Gumboro disease (IBD) at 15 days of age.

\subsection{Serum Collection}

Blood samples were collected from two groups at 7,21 and 31 days of age in a tube without anticoagulant for serum collection. Serum was collected after centrifugation at 3000 r.p.m for 15 minute and stored at $-20^{\circ} \mathrm{C}$ untiluse.

\subsection{Body Weight}

The live body weight was determined by weighting chicks of the two groups after 10 days and 34 days of the experiment.

\subsection{Estimation of Serum Biochemical Parameters}

Liver function tests were determined by a colorimetric methods as described using commercial kit as Aspartate Aminotransferase (AST) (Murray, 1984), Albumin (Doumas, 1971), Alkaline phosphates (Belfield and
Goldberg, 1971) and total protein (Burtis et al., 1999). Lipid profile test was determined calorimetrically, total cholesterol and triacylglycerol were determined according to (Schettler and Nussel, 1975), HDL- cholesterol according to (Gordon, 1977), LDL-cholesterol (Friedewald et al., 1972) and VLDL-cholesterol (Bauer, 1982). Serum CRP concentration was determined according to the method described by (Burtis et al., 1999). Interleukin2, Interleukin 6, Immunoglobulin IgG and Immunoglobulin IgM were determined by ELISA kits.

\subsection{Statical Analysis}

The results were expressed as mean \pm SE (S.E $=$ Standard error) using student's T- test according to (Steel and Torrie, 1980). Values were considered statistically significant when $\mathrm{p}<0.05$, 0.01 and 0.001 .

\section{Results}

\subsection{Effect of Inmunair 17.5® on Some Blood Parameters}

The obtained data in tables $(1,2$, and 3$)$ showed the effect of inmunair 17.5 on some blood parameters

- There were no significance in liver functions (AST, ALP), albumin and total protein between the two groups.

- There was significant decrease in $\mathrm{Na}$ concentration in inmunair group all over the experimental period but there was no significance in $\mathrm{Ca}$ concentration between the two groups.

- There was no significance in cholesterol, HDL and LDL concentrations but there was significant increase in triglycerides and VLDL concentrations in inmunair group at 31 days of age only.

- There was significant decrease in cortisol concentration in inmunair group in 7 and 21 days of age but no significance at 31 days of age.

- There were no significance in IL6 and CRP concentrations but there was significant increase in IL2 concentration in inmunair group at 31 days of age only.

- There was high significant increase in IgG concentration at 7 and 31 days of age, very high significant increase at 21 days of age, high significant increase in IgM at 7 and 21 days of age and high significant increase at 31 days of age. 
Metabolic Role of Non-Specific Immunostimulant (inmunair) in Advanced Healthly of Broilers

Table1. Effect of inmunair 17.5® on liver function and CRP after 7, 21 and 31 days of age

\begin{tabular}{|c|c|l|l|l|l|l|}
\hline & \multicolumn{2}{|c|}{ 7 Days } & \multicolumn{2}{c|}{ 21 Days } & \multicolumn{2}{c|}{ 31 Days } \\
\hline Parameters & Control group & Inmunair group & Control group & Inmunair group & Control group & Inmunair group \\
\hline total protein & $6.95 \pm 0.28$ & $7.40 \pm 0.21$ & $7.54 \pm 0.30$ & $8.33 \pm 0.59$ & $7.68 \pm 0.31$ & $8.49 \pm 0.60$ \\
\hline albumin & $3.38 \pm 0.15$ & $3.51 \pm 0.15$ & $3.67 \pm 0.16$ & $3.69 \pm 0.29$ & $3.74 \pm 0.16$ & $3.76 \pm 0.29$ \\
\hline AST & $82.13 \pm 5.27$ & $88.67 \pm 3.89$ & $89.05 \pm 5.71$ & $101.05 \pm 6.83$ & $90.78 \pm 5.82$ & $103.01 \pm 6.96$ \\
\hline ALP & $25.02 \pm 2.59$ & $31.03 \pm 2.76$ & $27.12 \pm 2.81$ & $25.75 \pm 0.59$ & $27.65 \pm 2.86$ & $26.25 \pm 0.61$ \\
\hline CRP & $3.97 \pm 0.34$ & $3.41 \pm 0.47$ & $4.31 \pm 0.37$ & $3.70 \pm 0.51$ & $4.39 \pm 0.38$ & $4.14 \pm 0.26$ \\
\hline
\end{tabular}

Data are presented as $($ Mean \pm S.E). S.E $=$ Standard error: * Represents statistical Significant at $P<0.05$,

$* *$ Represents statistical Significant at $P<0.01$ and $* * *$ Represents statistical Significant at $P<0.001$

Table 2: Effect of inmunair 17.5® on lipid profile, Na and Ca levels after 7, 21 and 31 days of age

\begin{tabular}{|c|l|l|l|l|l|l|}
\hline & \multicolumn{2}{|c|}{ 7 Days } & \multicolumn{2}{c|}{ 21 Days } & \multicolumn{2}{c|}{ 31 Days } \\
\hline Parameters & Control group & Inmunair group & Control group & Inmunair group & Control group & Inmunair group \\
\hline cholesterol & $58.65 \pm 3.71$ & $50.04 \pm 4.16$ & $63.59 \pm 4.02$ & $54.25 \pm 4.51$ & $64.82 \pm 4.10$ & $72.06 \pm 5.86$ \\
\hline triglycerides & $55.91 \pm 5.03$ & $58.94 \pm 3.51$ & $60.62 \pm 5.46$ & $63.90 \pm 3.81$ & $61.80 \pm 5.56$ & $83.65 \pm 3.65 *$ \\
\hline VLDL & $11.18 \pm 1.01$ & $11.97 \pm 0.57$ & $12.12 \pm 1.09$ & $12.98 \pm 0.62$ & $12.35 \pm 1.11$ & $16.73 \pm 0.73 *$ \\
\hline HDL & $22.10 \pm 1.25$ & $15.02 \pm 2.87$ & $23.96 \pm 1.35$ & $19.52 \pm 1.62$ & $24.42 \pm 1.38$ & $26.28 \pm 2.63$ \\
\hline LDL & $25.37 \pm 3.80$ & $20.04 \pm 3.58$ & $27.51 \pm 4.12$ & $21.73 \pm 3.89$ & $28.04 \pm 4.20$ & $29.05 \pm 8.95$ \\
\hline Na & $136.87 \pm 3.91$ & $116.53 \pm 2.47 *$ & $148.43 \pm 4.27$ & $127.15 \pm 3.97 *$ & $151.28 \pm 4.32$ & $129.62 \pm 4.05 *$ \\
\hline Ca & $8.35 \pm 1.05$ & $8.43 \pm 1.10$ & $9.05 \pm 1.14$ & $8.19 \pm 1.43$ & $9.23 \pm 1.16$ & $8.35 \pm 1.46$ \\
\hline
\end{tabular}

Data are presented as $($ Mean \pm S.E). S.E $=$ Standard error: * Represents statistical Significant at $P<0.05$,

$* *$ Represents statistical Significant at $P<0.01$ and $* * *$ Represents statistical Significant at $P<0.001$

Table3. Effect of inmunair 17.5® on cortisol, interleukins and immunoglobulins after 7, 21 and 31 days of age

\begin{tabular}{|l|r|r|l|l|r|c|}
\hline & \multicolumn{2}{|c|}{7 Days } & \multicolumn{2}{c|}{ 21 Days } & \multicolumn{2}{c|}{ 31 Days } \\
\hline Parameters & Control group & Inmunair group & Control group & Inmunair group & Control group & Inmunair group \\
\hline Cortisol & $6.90 \pm 0.46$ & $4.65 \pm 0.48 *$ & $7.48 \pm 0.49$ & $5.04 \pm 0.52 *$ & $7.62 \pm 0.50$ & $7.85 \pm 1.08$ \\
\hline IL-2 & $0.37 \pm 0.03$ & $0.45 \pm 0.04$ & $0.40 \pm 0.03$ & $0.49 \pm 0.05$ & $0.41 \pm 0.03$ & $0.62 \pm 0.05 *$ \\
\hline IL-6 & $5.06 \pm 0.78$ & $5.48 \pm 0.54$ & $5.49 \pm 0.85$ & $5.94 \pm 0.58$ & $5.60 \pm 0.86$ & $6.93 \pm 0.34$ \\
\hline IgG & $181.69 \pm 4.65$ & $232.33 \pm 2.05 * *$ & $167.97 \pm 2.47$ & $261.18 \pm 3.88 * * *$ & $177.87 \pm 5.74$ & $275.26 \pm 17.17 * *$ \\
\hline IgM & $28.53 \pm 2.12$ & $44.92 \pm 1.79 * *$ & $26.80 \pm 3.42$ & $75.31 \pm 8.57 * *$ & $36.17 \pm 2.17$ & $85.46 \pm 3.29 * * *$ \\
\hline
\end{tabular}

Data are presented as $($ Mean \pm S.E). S.E $=$ Standard error: $*$ Represents statistical Significant at $P<0.05$,

$* *$ Represents statistical Significant at $P<0.01$ and $* * *$ Represents statistical Significant at $P<0.001$

Table4. Effect of inmunair 17.5® on body weights after 10 and 34 days of age

\begin{tabular}{|l|c|c|}
\hline \multirow{2}{*}{\multicolumn{1}{|c|}{ Groups }} & \multicolumn{2}{|c|}{ Experimental Period } \\
\cline { 2 - 3 } & 10 Days & 34 Days \\
\hline Control group & $466.67 \pm 16.67$ & $2000.00 \pm 115.47$ \\
\hline Inmunair group & $493.33 \pm 6.67$ & $2166.67 \pm 202.76$ \\
\hline
\end{tabular}

Data are presented as (Mean \pm S.E). S.E $=$ Standard error

\subsection{Body Weight}

There was non significant increase in inmunair group at 10 days of age (5\%) and 34 days of age $(8 \%)$.

\section{DISCUSSION}

It is a significant to get a good immune response to prevent diseases in poultry with minimal or no damages. So, the use of immunostimulants is a resolution to enhance bird's resistance to infectious diseases. Our results revealed that there was no significance in liver functions between the two groups. These results are in agreement with (Ferrer et al., 2013) who investigated that oral administration of killed p.acnes $(0.17 \mathrm{mg} \backslash \mathrm{ml})$ has no significance on albumin and total protein and (Peñailillo et al., 2016) who demonstrated that there was no significance in values of TP, albumin and AST after two intravenous administrations of (1 $\mu \mathrm{g} / \mathrm{kg} \mathrm{bw}$ ) of E. coli LPS at $6 \mathrm{~h}$ interval in adult rabbits. He also demonstrated that there was significant increase in CRP and IL6 for $24 \mathrm{~h}$ after injection. It is known that increasing IL6 
induces fever (Roth et al., 2006) and this doesn't agree with this study may be because we used LPS by oral route and with small concentration.

There was significant increase in IL2 at 31 days of experiment only. This is in agreement with (Nordgreen et al., 2018) who showed that there was no significance in IL2 injected with LPS (1.5 $\mu \mathrm{g} \mathrm{kg}-1 \mathrm{IV})$

This study revealed that there was significant decrease in cortisol at 7 and 21 days of age in inmunair group that is in agreement with (Adams et al., 2016) who studied the effect of IV administration of immunostimulant containing P.acnes and found that cortisol as marker of stress decreased significantly with p.acnes administration.

There was significant increase in TG and VLDL at 31 days of age only but non significance in cholesterol, HDL and LDL (harmful cholesterol) all over experimental period so the risk factor for heart disease is very low.

There was significant decrease in $\mathrm{Na}$ concentration in inmunair group allover experimental period but this decrease is in the normal value in the chicken which is that is, 122-160 mmol/1 in chickens (Puls, 1990) which means that no disturbance of acid-base balance occurred.

There was high significant increase in immunoglobulins $\operatorname{IgG}$ and $\operatorname{IgM}$ all over the experimental period this is in agreement with (Stipkovits et al., 2016) who studied the effect administration of inmunair 17.5 on chickens infected with micoplasma gallisepticum and treated with tetracycline which give higher specific IgG and IgM values in inmunair group. This also is with agreement with (Kim et al., 2011) who showed that injections of E.coli LPS $(500 \mathrm{mg} / \mathrm{kg}$ of body weight) at 10 weeks of age in calves give a significant increase in total plasma IgG. However, such change was not observed in total serum IgM.

The increase in body weight was not high $5 \%$ at 10 days of age and $8 \%$ at 34 days of age. This is in agreement with (Abdel-Hafez and Mohamed, 2016) who found that the increase in body weight was low in broilers supplemented with inmunair $17.51 .5 \mathrm{ml} / \mathrm{L}$ to drinking water for 24 hours at the first three days of every week. This is not in agreement with (Mousa et al., 2018) who found that there was significant increase $(14.3 \%)$ in body weight in New Zealand white rabbits at 13 weeks of age which received $1 \mathrm{~m} / 1$ liter in drinking water for three days at five weeks of age.

\section{CONCLuSiON}

The obtained results show that inmunair $17.5 \AA$ can be used as a safe immunostimulant that can reduce stress after vaccination and cause antibody response in broilers.

\section{CONFLICT OF INTEREST}

The authors declare no conflict of interest

\section{REFERENCES}

[1] Abdel-Hafez M.S., Mohamed M. A.(2016) Evaluation of Some Immunostimulants on the Immune-response of Broiler Chickens Against Avian Influenza and Newcastle Diseases Vaccination. Zagazig Veterinary Journal, 44 (3) :273-281

[2] Adams A.A. , Elzinga S., Lyman J., Little J. (2016) Effects of an Immunostimulant Containing Propionibacterium acnes (EqStim) on Cell-Mediated Immunity and Nasal Shedding of Respiratory Pathogens Using a Model of "Weaning" Stress in Foals. Journal of Equine Veterinary Science 38: 72-81.

[3] Bauer JD.(1982) "Clinical laboratory methods" 9th Ed, the C.V.Company Waistline Industrial Missouri 63116 Chapter 33:555.

[4] Belfield A, Goldberg DM (1971) Revised assay for serum phenylphosphatase activity using 4 aminoantipyrine. Enzyme 12:561-573.

[5] Burtis A, Carl A, Edward R, Ashwood MD. (1999) Tietz Textbook ofClinical Chemistry 3rd Edition,.

[6] Doumas B.(1971) Colorimetric determination of albumin. Clinical ChemicalActa,.

[7] Ferrer L.M., Fernández A., Loste A., Ortín A., Lacasta D., Ramos J.J., Verde M.T. \&Conde T. (2013) Effect of oral administration ofPropionibacterium acnes on growth performance, DTH response and anti-OVA titers in goat kids. Pesq. Vet. Bras. 33(1):5-10

[8] Flaminio M.J.B., Rush B.R. \& Shuman W. 1998. Immunologic functionin horses after nonspecific immunostimulant administration. Vet. Immunol. Immunopathol. 63:303-315.

[9] Friedewald W, Levy R, Fredrickson D.(1972) Estimation of the concentration of low-density lipoprotein cholesterol in plasma, without use of thepreparative ultracentrifuge. Clin. Chem; 18:499-502. 
[10] Gordon T. (1977) Colorimetric determination of serum HDLcholesterol. Amer.J. Med; 62: 707.

[11] Kim M. H., Yun C. H., Kim G. R., Ko J. Y. , Lee J.J and Jong K. Ha.(2011) Changes of Immunoglobulins and Lymphocyte Subpopulations inPeripheral Blood from Holstein Calves Challenged with Escherichia coli Lipopolysaccharide. Asian-Aust. J. Anim. Sci. 24 (5) : $696-706$

[12] Megid J. \&Kaneno R. 2000. Natural killer activity in mice infectedwith rabies virus submitted to P. acnes (Propionibacterium acnes) as immunomodulator. Comp. Immunol. Microbiol. Infect. Dis. 23:91-97.

Citation: Mahfouz M.K, Omyma A.R, Abd El-maksoud H.A, Abd El-fattah S.A, Sohyla G.M. Metabolic Role of Non-Specific Immunostimulant (inmunair) in Advanced Healthly of Broilers. ARC Journal of Nutrition and Growth. 2020; 6(2):1-5. DOI: https://doi.org/10.20431/2455-2550.0602001.

Copyright: (C) 2020 Authors. This is an open-access article distributed under the terms of the Creative Commons Attribution License, which permits unrestricted use, distribution, and reproduction in any medium, provided the original author and source are credited. 